\title{
LASER WELDING OF THE NEW GRADE OF ADVANCED HIGH-STRENGTH STEEL DOMEX 960
}

\section{LASERSKO VARJENJE DOMEX 960 NOVEGA NAPREDNEGA JEKLA Z VISOKO TRDNOSTJO}

\author{
Agnieszka Kurc-Lisiecka ${ }^{1}$, Aleksander Lisiecki ${ }^{2}$ \\ ${ }^{1}$ University of Dąbrowa Górnicza, Rail Transport Department, Cieplaka 1C, 41-300 Dąbrowa Górnicza, Poland \\ ${ }^{2}$ Silesian University of Technology, Faculty of Mechanical Engineering, Welding Department, Konarskiego 18A, 44-100 Gliwice, Poland \\ a.kurc@wp.pl, aleksander.lisiecki@polsl.pl \\ Prejem rokopisa - received: 2015-07-01; sprejem za objavo - accepted for publication: 2016-02-09
}

doi:10.17222/mit.2015.158

The article presents the results of investigations on autogenous laser welding of the new-generation advanced high-strength steels (AHSS) Domex 960, classified as thermomechanically rolled steel by the manufacturer. There is little information about welding this steel grade, relating only to arc-welding methods. Therefore, a modern disk laser was used for the butt-joint welding of $5.0 \mathrm{~mm}$ steel sheets. The results of a microstructure study, tensile tests, technological bending tests, impact-toughness tests and also microhardness measurements showed that a low heat input during the laser welding of the new Domex 960 grade steel is advantageous. A low heat input and thus a high cooling rate of the weld metal and the heat-affected zone (HAZ) led to the formation of a favourable fine-grained microstructure, providing also high mechanical properties of butt joints, comparable to the properties of the base metal. Despite the high cooling rates, there was no significant increase in the microhardness measured across the butt joints. Moreover, a slight decrease in the microhardness was observed in the HAZ.

Keywords: laserlaser welding, disk laser, thermomechanically rolled steel, advanced high-strength steel, fine-grained steel, properties of welded joints

Članek predstavlja rezultate preiskav avtogenega laserskega varjenja nove generacije naprednih visokotrdnostnih jekel (AHSS), jekla Domex 960, ki so ga proizvajalci opredeljujejo kot termomehansko valjano jeklo. Malo je informacij o varjenju te vrste jekla, nekaj le za metode obločnega varjenja. Za soležno varjenje $5 \mathrm{~mm}$ debelih pločevin je bil uporabljen modern diskasti laser. Rezultati študija mikrostrukture, nateznih preizkusov, tehnoloških upogibnih preizkusov, preizkusov udarne žilavosti in tudi meritev mikrotrdote, so pokazali, da je ugoden majhen vnos toplote med laserskim varjenjem nove vrste jekla Domex 960. Majhen vnos toplote in zato velika hitrost ohlajanja kovine v zvaru in v toplotno vplivani coni (HAZ), povzroči nastanek željene drobno zrnate mikrostrukture in tudi zagotavlja visoke mehanske lastnosti soležnega zvara, v primerjavi z lastnostmi osnovne kovine. Kljub velikim hitrostim ohlajanja, ni bilo občutnega povečanja mikrotrdote, izmerjene preko soležnega zvara. Poleg tega je bilo v HAZ opaženo rahlo zmanjšanje mikrotrdote.

Ključne besede: lasersko varjenje, diskasti laser, termomehansko valjano jeklo, napredna visokotrdnostna jekla, drobno zrnato jeklo, lastnosti zvarjenih spojev

\section{INTRODUCTION}

The constant trend to increase production efficiency, reduce energy consumption and material consumption, improve the durability and reliability has lead to an increasing use of advanced high-strength materials. ${ }^{1-8}$ Depending on the application, working conditions and the type of load and wear, different metallic, bimetallic or composite materials are used. ${ }^{9-12}$

In the case of the manufacturing of building structures such as bridges, towers, industrial buildings and vehicles, particularly heavy vehicles such as trucks, trailers, semi-trailers, rail vehicles such wagons and tramcars, and also other utility vehicles and machines such as cranes, loaders, excavators, etc., the primary group of materials is structural steel. ${ }^{13-18}$ The reason for this is the ease of forming and joining steel pieces, usually with welding technologies. Moreover, the use of high-strength steel (HSS) has been growing in the industry for many years. The dynamic development of high-strength steels has led to the introduction of modern advanced and ultra-high-strength steels (AHSS and UHSS), characterized by an extremely high yield point and tensile strength over $1000 \mathrm{MPa} .{ }^{1-8}$ Steels of this type achieve high mechanical properties thanks to a very fine-grained structure and/or a sophisticated phase composition like in the case of dual-phase (DP), complexphase (CP) and transformation-induced plasticity (TRIP) steels. ${ }^{2,6,7}$

A significant group of the modern structural steels currently used in the industry includes thermomechanically rolled fine-grained microalloyed steel classified by the EN 10149-2 standard and also the quenched and tempered low-alloy steel classified by the EN 10025-6 standard. The EN 10149-2 standard covers the thermomechanically rolled fine-grained microalloyed steel with a yield point of up to $700 \mathrm{MPa}$ (e.g., S700MC). An example of the commercial name of this type of steel is Domex 700, manufactured by a Swedish company. On the contrary, the EN 10025-6 standard covers the low-alloy quenched and tempered steel with a yield point 
of up to $960 \mathrm{MPa}$ (e.g., S960QL). An example of the commercial name in this case is Weldox 960.

Steels of the above groups differ in the chemical composition and manufacturing procedure, even if they have similar mechanical properties, as shown in Table 1. Differences in the chemical composition affect the carbon equivalent $C_{\mathrm{e}}$, thus the hardenability and the associated susceptibility to cold cracking (hydrogen cracking). ${ }^{15,20-22}$ Beside the chemical composition, structural constituents, especially the strengthening precipitations like carbides, borides or nitrides, also influence the requirements and specification of the welding procedure.

Table 1: Chemical composition of S700MC steel according to EN 10149-2

Tabela 1: Kemijska sestava jekla S700MC, skladno z EN 10149-2

\begin{tabular}{|c|c|c|c|c|c|c|c|c|}
\hline $\mathrm{C}$ & $\mathrm{Si}$ & $\mathrm{Mn}$ & $\mathrm{Al}$ & $\mathrm{Nb}$ & $\mathrm{V}$ & $\mathrm{Ti}$ & $\mathrm{Mo}$ & $\mathrm{B}$ \\
\hline 0.12 & 0.6 & 2.1 & 0.015 & 0.09 & 0.2 & 0.22 & 0.5 & 0.005 \\
\hline
\end{tabular}

CEV max $=0.38$, CET $\max =0.25$

As a result of an intensive research and a dynamic development of modern steel grades, the world's largest steel manufacturers now offer steels with properties that go beyond the standards. Examples are steel grades Weldox 1100 or Weldox 1300 classified as quenched and tempered steel, suitable for welding. Additionally, new steel grades, such as Domex 960, are available in the market. The Domex 960 steel grade is classified by the manufacturer as a thermomechanically rolled steel even though the properties of this steel are at the level of quenched and tempered Weldox 960.

Thus, with the introduction of new grades of steel, the classification becomes more difficult.

The reason for this is a very sophisticated chemical composition, the combination of individual elements and also the sophisticated manufacturing process. It should also be noted that the chemical composition of these steels depends on their thickness. In addition, there are also significant differences between individual melts of steel. Moreover, the manufactures continue the research of how to modify the chemical composition in terms of the optimum combination of mechanical properties and weldability.

Such sophisticated steels also require sophisticated welding procedures and welding technologies. ${ }^{19,23}$ Unfortunately, the manufactures provide only limited information about the welding, relating only to conventional arc-welding processes such gas metal arc (GMA), gas tungsten arc (GTA) or submerged-arc welding (SMAW).

At the same time, general guidelines for welding thermomechanically rolled fine-grained microalloyed steel grade such as Domex and low-alloy quenched and tempered steel such as Weldox are different. Generally, in the case of thermomechanically rolled fine-grained microalloyed steel, it is recommended not to exceed a certain heat input because it causes a drop in mechanical properties and impact toughness. On the other hand, in the case of low-alloy quenched and tempered steel, the heat input must be within a specific range. Too high a heat input causes a drop in the toughness, like in the case of the fine-grained microalloyed steel. On the other hand, too low a heat input can lead to cold cracking of a joint. Therefore, according to the manufacturer's instructions, the recommended cooling time $t_{8 / 5}$ between temperature ranges from $800{ }^{\circ} \mathrm{C}$ to $500{ }^{\circ} \mathrm{C}$ is $5 \mathrm{~s}$ to $15 \mathrm{~s}$ for Weldox 900 to 1300 . As laser welding is of an increasing importance in the industry and the conditions of laser welding are radically different from arc welding, a research of the laser welding of new steel grade Domex 960 was undertaken in this work. ${ }^{24,25}$

\section{EXPERIMENTAL PART}

The steel chosen for the investigation was the new generation of advanced high-strength steel (AHSS) Domex 960, recently introduced to the industry by a Swedish company. The new grade of steel Domex 960 is included, by the manufacturer, in the group of thermomechanically rolled fine-grained microalloyed steels covered by the EN 10149-2 standard. However, the mechanical properties of steel Domex 960 go far beyond the steels specified in this standard. Additionally, details of the manufacturing process for the new steel grade are undisclosed. The investigated steel with the nominal chemical composition of $0.18 \% \mathrm{C}, 0.5 \% \mathrm{Si}, 2.1 \% \mathrm{Mn}$ and $0.018 \% \mathrm{Al}$ in $\%$ of mass fractions and balanced $\mathrm{Fe}$ has the minimum yield strength of $960 \mathrm{MPa}$ and the minimum tensile strength of $980 \mathrm{MPa}$.

Specimens for the test involving laser welding were cut from a $5.0 \mathrm{~mm}$ steel plate into coupons with dimensions of $100.0 \times 100.0 \mathrm{~mm}$, using a 2D laser cutting machine with a $\mathrm{CO}_{2}$ generator. Surfaces to be welded were sandblasted and then cleaned with acetone. The trials of welding were performed by means of a solidstate Yb:YAG disk laser emitted in the continuous-wave mode at a wavelength of $1.03 \mu \mathrm{m}$ with the maximum output power of $3.3 \mathrm{~kW}$. The laser beam was focused to a diameter of $200 \mu \mathrm{m}$.

First, the bead-on-plate welds were produced at the maximum output laser power of $3.3 \mathrm{~kW}$ and welding speeds of $(0.5,1.0,1.5$ and 2.0$) \mathrm{m} / \mathrm{min}$. The bead-onplate welds were produced to simulate the process of butt-joint welding and to investigate the influence of welding parameters on the penetration depth and weld shape. Based on the bead-on-plate welding trials, the optimum parameters for butt joints were chosen. Butt joints were single-side autogenously laser welded at the maximum laser power of $3.3 \mathrm{~kW}$ and welding speeds of $1.0 \mathrm{~m} / \mathrm{min}$ and $1.5 \mathrm{~m} / \mathrm{min}$, respectively. The specimens to be welded were mounted to a clamping device to be protect against distortions. The weld pool was protected by an argon flow via four cylindrical nozzles of $8.0 \mathrm{~mm}$ in diameter and set at an angle of $45^{\circ}$ to the joint surface. The flow of argon was kept at $15 \mathrm{~L} / \mathrm{min}$. The laser beam 
was focused on the top surface of the specimens to be welded. When the laser-welding tests were completed, the first the visual inspections (VT) were performed according to the procedure of quality control in welding. Next, the metallographic and also mechanical examinations were done. The examination of the structure was carried out by means of optical microscopes (OM) and a scanning electron microscope (SEM). The chemical composition of the base metal was determined with a glow discharge spectrometer (GDS). On the other hand, mechanical tests included a technological bending test, a static tensile test and a Charpy V-notch test.

\section{RESULTS AND DISCUSSION}

The trials of bead-on-plate welding with a disk laser showed that the heat input required for a full penetration of a $5.0 \mathrm{~mm}$ plate of the Domex 960 steel is at least 100
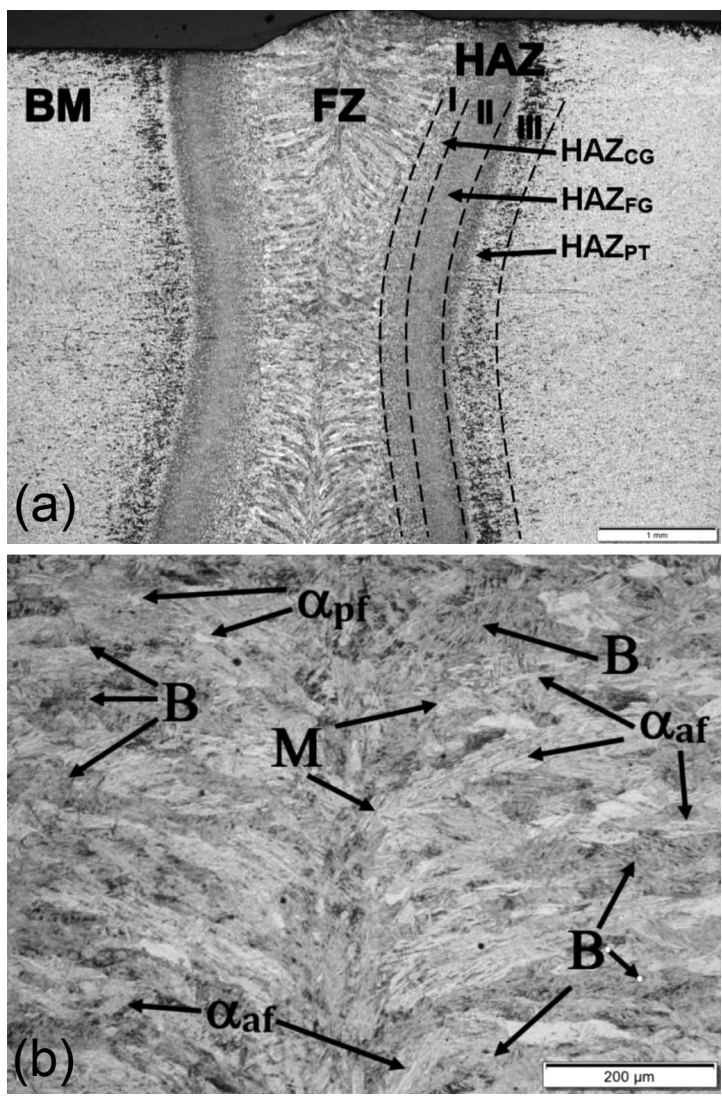

Figure 1: a) Macrostructure of the butt joint produced at the welding speed of $1.5 \mathrm{~m} / \mathrm{min}$, thus the heat input of $132 \mathrm{~J} / \mathrm{mm}, \mathrm{b}$ ) and the microstructure of the weld metal (FZ)

$\mathrm{BM}$ - base metal, FZ - fusion zone, HAZ - heat-affected zone, HAZ $\mathrm{CG}_{\mathrm{C}}$ coarse-grained region, $\mathrm{HAZ}_{\mathrm{FG}}$ - fine-grained region, $\mathrm{HAZ}_{\mathrm{PT}}-$ partially transformed region, B - bainite, $\mathrm{M}-$ martensite, $\alpha_{\mathrm{pf}}$ - polygonal ferrite, $\alpha_{\mathrm{af}}-$ allotriomorphic ferrite

Slika 1: a) Makrostruktura soležnega zvara, izdelanega s hitrostjo varjenja $1,5 \mathrm{~m} / \mathrm{min}$, vnos toplote $132 \mathrm{~J} / \mathrm{mm}$ in b) mikrostruktura zvarjene kovine (FZ)

$\mathrm{BM}$ - osnovna kovina, FZ - področje taljenja, HAZ - toplotno vplivana cona, $\mathrm{HAZ}_{\mathrm{CG}}$ - področje velikih zrn, $\mathrm{HAZ}_{\mathrm{FG}}$ - področje drobnih zrn, $\mathrm{HAZ}_{\mathrm{PT}}-$ delno transformirano področje, B - bainit, $\mathrm{M}$ - martenzit, $\alpha_{\mathrm{pf}}$ - poligonalni ferit, $\alpha_{\mathrm{af}}$ alotriomorfni ferit
$\mathrm{J} / \mathrm{mm}$, at a laser output power of $3.3 \mathrm{~kW}$ and a welding speed of $2.0 \mathrm{~m} / \mathrm{min}$. The width of a weld face produced at the minimum welding heat input is $2.15 \mathrm{~mm}$, while the root width is $0.8-1.27 \mathrm{~mm}$. In this case the depth/width ratio is over 2.3, indicating that the laser welding mode was the keyhole mode. Additionally, the shape of the fusion zone (FZ) in a columnar or hour-glass configuration (X shape) is characteristic for keyhole laser welding at a high power density of the laser beam. An increase in the heat input of laser welding, by lowering the welding speed at a constant laser power, increases the width of a single bead-on-plate weld and the width of the heat affected zone (HAZ).

The visual inspections (VT) of the test butt joints revealed a proper shape of the welds, and proper reinforcement of weld faces and roots. Macrographs of the test joints showed a proper shape of the fusion lines and no internal imperfections (Figure 1a). A high quality of the test joints was also confirmed with microscopic observations (Figure 1b) and mechanical tests. The technological bending test revealed no tendency to cracking of the welded joints, both in the weld and in the HAZ, even at the maximum angle of bending. On the other hand, the static tensile tests showed high strength of laser-welded joints at the level of the base metal (BM).
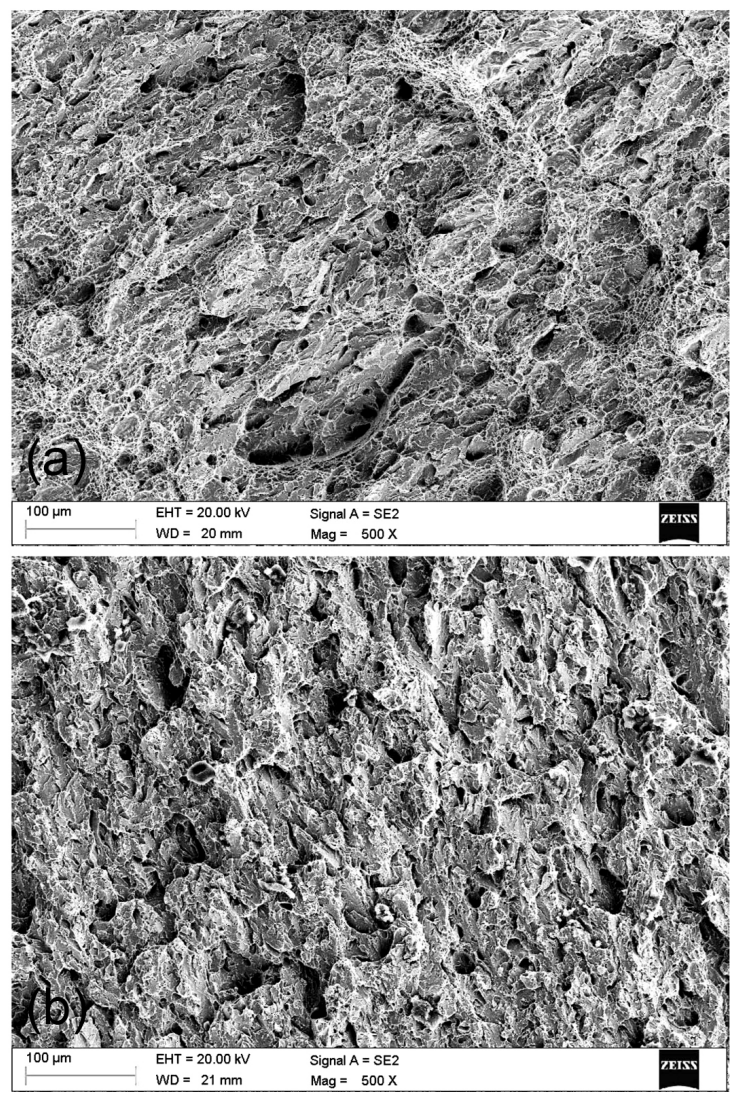

Figure 2: SEM micrographs of the fracture surface of the test joint produced at: a) the heat input of $198 \mathrm{~J} / \mathrm{mm}$ and b) the heat input of 132 $\mathrm{J} / \mathrm{mm}$

Slika 2: SEM-posnetek površine preloma preizkusnega spoja izdelanega $\mathrm{z}$ vnosom toplote: a) $198 \mathrm{~J} / \mathrm{mm}$ in b) vnosom toplote $132 \mathrm{~J} / \mathrm{mm}$ 
Table 2: Chemical composition of S690QL steel according to EN 10025-6

Tabela 2: Kemijska sestava jekla S690QL, skladno z EN 10025-6

\begin{tabular}{|c|c|c|c|c|c|c|c|c|c|c|c|c|}
\hline $\mathrm{C}$ & $\mathrm{Si}$ & $\mathrm{Mn}$ & $\mathrm{B}$ & $\mathrm{Cr}$ & $\mathrm{Cu}$ & $\mathrm{Mo}$ & $\mathrm{N}$ & $\mathrm{Nb}$ & $\mathrm{Ni}$ & $\mathrm{Ti}$ & $\mathrm{V}$ & $\mathrm{Zr}$ \\
\hline 0.12 & 0.8 & 1.7 & 0.005 & 1.5 & 0.5 & 0.7 & 0.015 & 0.06 & 2.0 & 0.05 & 0.12 & 0.15 \\
\hline
\end{tabular}

CEV max $=0.65$, CET standard $=0.29$

All of the tested samples broke out of the joint area in the base metal at a tensile strength of $1093 \mathrm{MPa}-1017$ MPa. The Charpy V-notch test, performed at room temperature, showed that the impact toughness of the test butt joints is clearly lower compared to the base metal. The results of the impact toughness determined for the base metal were very consistent, ranging from $128 \mathrm{~J} / \mathrm{cm}^{2}$ to $134 \mathrm{~J} / \mathrm{cm}^{2}$. The average value was $131.3 \mathrm{~J} / \mathrm{cm}^{2}$. The impact toughness of the test joint welded at a heat input of $198 \mathrm{~J} / \mathrm{mm}$ was in a range of $82 \mathrm{~J} / \mathrm{cm}^{2}-98 \mathrm{~J} / \mathrm{cm}^{2}$, at the average value of $90 \mathrm{~J} / \mathrm{cm}^{2}$. So, the impact toughness of this joint is as low as $68 \%$ of the base-metal toughness. On the contrary, the impact toughness of the second test joint welded at a low heat input of $132 \mathrm{~J} / \mathrm{mm}$ is 70.7 $\mathrm{J} / \mathrm{cm}^{2}$, so just $53 \%$ of the base-metal toughness.

SEM micrographs of the fracture surfaces of the test joints are presented in Figure 2. As can be seen, the fracture surfaces indicate a typical ductile dimple fracture mode in both cases. So, although the impact toughness of the test joints is clearly lower compared to the base metal, the fracture mode is ductile. The results indicate that the impact toughness of the test butt joints depends directly on the heat input of autogenous laser welding within the investigated range of parameters, i.e., thermal conditions, cooling rates and the structures of the weld metal and the HAZ.

The cooling times $t_{8 / 5}$ between $800{ }^{\circ} \mathrm{C}$ and $500{ }^{\circ} \mathrm{C}$ were calculated for different heat inputs of laser welding by means of an equation adopted for the conditions of keyhole laser welding, as described in details in ${ }^{4}$. For the heat input of $198 \mathrm{~J} / \mathrm{mm}$ for the butt laser welding of the $5.0 \mathrm{~mm}$ steel plates, the calculated cooling time $t_{8 / 5}$

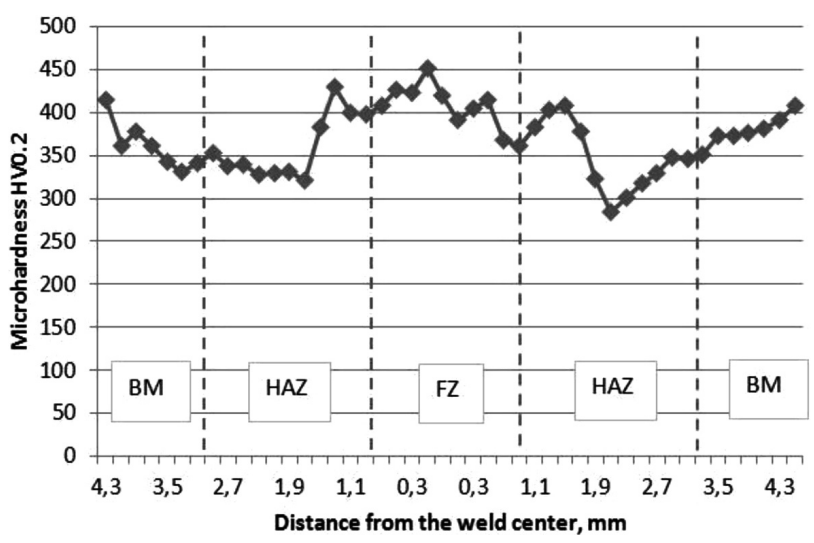

Figure 3: Microhardness distribution on the cross-section of the butt joint produced at the heat input of $132 \mathrm{~J} / \mathrm{mm}$

Slika 3: Razporeditev mikrotrdote po preseku soležnega spoja, izdelanega pri vnosu toplote $132 \mathrm{~J} / \mathrm{mm}$ was $1.299 \mathrm{~s}$. However, the cooling time in the case of a lower heat input of $132 \mathrm{~J} / \mathrm{mm}$ was just $0.577 \mathrm{~s}$. For comparison, in both cases, cooling times $t_{8 / 5}$ are significantly lower than recommended for the quenched and tempered Weldox grade steel, being in the range of $5 \mathrm{~s}-15 \mathrm{~s}$. However, despite such short cooling times there was no tendency to cold (hydrogen) cracking of the test joints (Figure 1).

The microhardness profiles determined on the cross-sections of the welded butt joints show a clear increase in the microhardness values in the region of the weld metal, i.e., the fusion zone, compared to the microhardness of the base metal, which is about $370 \mathrm{HV} 0.2$ (Figure 3). The microhardness distribution across the FZ is stable and maintained in a range of 360-440, while the mean value of microhardness in the FZ region is about $404 \mathrm{HV} 0.2$. On the other hand, the distribution of microhardness in the HAZ is more complex, so the HAZ can be divided into at least two areas: the inner HAZ adjacent to the FZ and the outer HAZ adjacent to the BM. From the side of the base metal, roughly in the middle of the HAZ, the microhardness decreases gradually from 370 to the minimum value of 290-300 HV0.2 and then it rises sharply up to over $400 \mathrm{HV} 0.2$ in the inner HAZ.

The microhardness in individual regions depends directly on the microstructure and this, in turn, depends on the chemical composition and the tendency to hardening. The GDS analysis showed that the investigated steel contains $0.161 \% \mathrm{C}, 0.31 \% \mathrm{Si}, 1.32 \% \mathrm{Mn}, 0.15 \%$ $\mathrm{Cr}, 0.05 \% \mathrm{Ni}, 0.41 \% \mathrm{Mo}, 0.043 \% \mathrm{Al}, 0.01 \%$ of V, Ti, $\mathrm{Cu}$ and $0.001 \% \mathrm{Nb}$. Based on the determined compo-

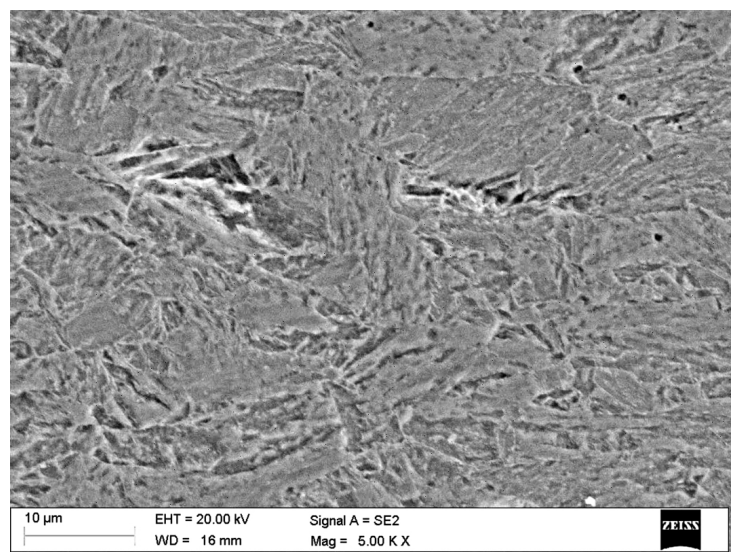

Figure 4: SEM micrograph showing the structure of the base metal of Domex 960 steel at a magnification of 5000x

Slika 4: SEM-posnetek strukture osnovne kovine jekla Domex 960 pri povečavi $5000 \times$ 

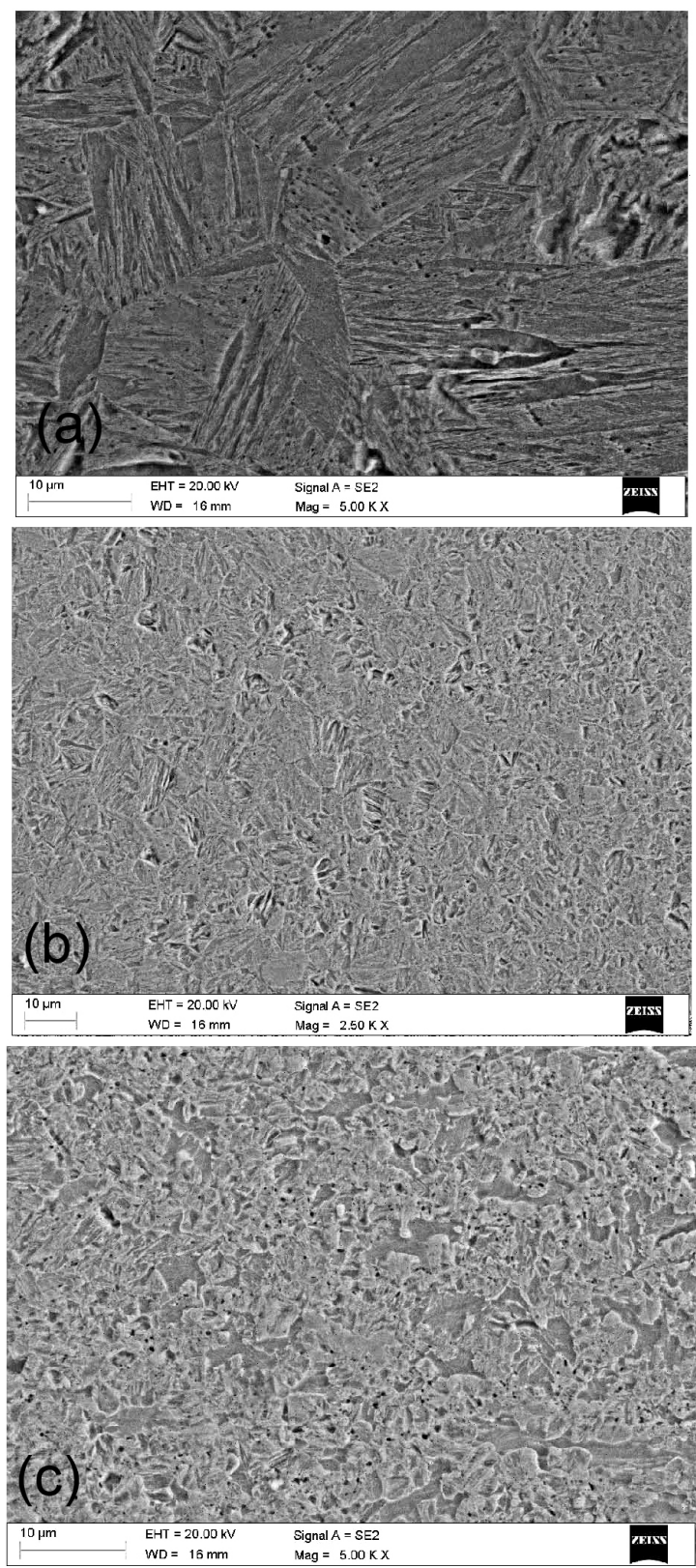

Figure 5: SEM micrographs showing the structure of the weld metal of the butt joint produced at the heat input of: a) $132 \mathrm{~J} / \mathrm{mm}$, b) the HAZ region adjacent to the fusion zone and c) the recrystallized finegrained region of the HAZ

Slika 5: SEM-posnetek structure zvara soležnega spoja izdelanega $z$ vnosom toplote: a) $132 \mathrm{~J} / \mathrm{mm}$, b) področje $\mathrm{HAZ} \mathrm{v}$ bližini področja pretaljevanja in c) rekristalizirano drobnozrnato področje HAZ

sition, the martensitic transformation temperature was calculated according to the following equation: $\mathrm{Ms}\left({ }^{\circ} \mathrm{C}\right)$ $=561-474(\% \mathrm{C})-33(\% \mathrm{Mn})-17(\% \mathrm{Ni})-17(\% \mathrm{Cr})$ - 21 (\% Mo). The calculated Ms temperature is $429.1^{\circ} \mathbf{C}$. Additionally, the carbon equivalent (CET) was determined according to the following equation: $\mathrm{CET}=\mathrm{C}+$ $(\mathrm{Mn}+\mathrm{Mo}) / 10+(\mathrm{Cr}+\mathrm{Cu}) / 20+\mathrm{Ni} / 40$. The value of the calculated CET is 0.343 . Both the high Ms temperature and the relatively low carbon equivalent indicate that the hardenability of the investigated steel is not very high.
The structure of the base metal of the Domex 960 steel is shown in Figure 4. In general, the investigated steel has a fine-grained bainitic-martensitic structure. A closer view at the structure exhibits quite a complex arrangement of different phases. The dominant structural constituent is bainite with a significant amount of needle-shaped low-carbon martensite. Beside the main structural constituents, ferrite and also traces of retained austenite can be identified. Additionally, small carbides with a high dispersion can be identified in the structure.

The structure of the HAZ depends on the distance from the fusion line and thus the thermal cycle and the related cooling rate. The thermal conditions during the liquid-metal solidification, especially in the HAZ, may be estimated on the basis of calculated cooling times $t_{8 / 5}$. The calculated cooling times in the range of $0.6-1.3$ are very short and indicate that the solidification as well as the cooling rates were very high under the laser-welding conditions. The HAZ may be divided into three distinguishable regions with different structures (Figure 1a). The first characteristic region of the HAZ is adjacent to the fusion line. In this region, due to high temperatures, a slight grain growth occurs. In this region, the structure is bainitic with a higher share of ferrite compared to the BM (Figures 1a, 5b). Next, a recrystallized fine-grained region with fine-grained bainite as the dominant structural constituent may be distinguished, characterized by a microhardness in the range of 380-420 HV0.2, Figure 3. Finally, a partially transformed and tempered region with a bainitic-ferritic structure may be distinguished (Figure 5c). A relatively high share of ferrite in this region is responsible for a gradual microhardness decrease to 280-310 HV0.2, as shown in Figure 3 .

The structure of the weld metal of the butt joint produced at a heat input of $132 \mathrm{~J} / \mathrm{mm}$ is presented in Figures $\mathbf{1 b}$ and $\mathbf{5 a}$. The structure consists mainly of bainite, a smaller amount of fine martensitic islands and also of ferrite, mainly polygonal $\left(\alpha_{\mathrm{pf}}\right)$ and allotriomorphic ferrite $\left(\alpha_{\mathrm{af}}\right)$, as shown in Figures $\mathbf{1 b}$ and $\mathbf{5 a}$.

\section{CONCLUSIONS}

The investigated new steel grade Domex 960 is characterized by a low content of alloying elements (microalloyed steel), thus the low carbon equivalent (CET) is 0.343 and the relatively high temperature of martensitic transformation (Ms) is about $429{ }^{\circ} \mathrm{C}$. Despite the low carbon equivalent, the base metal has a finegrained bainitic-martensitic structure with a microhardness of 370-380 HV0.2. The calculated cooling times $t_{8 / 5}$ under the investigated laser-welding conditions are very short, being in a range of $0.6 \mathrm{~s}-1.3 \mathrm{~s}$, so significantly shorter than the recommended values for the quenched and tempered steel grades such as Weldox. Despite a very rapid solidification of the weld metal and cooling, the test joints exhibit a high tensile strength, being at the 


\section{MATERIALI IN TEHNOLOGIJE/MATERIALS AND TECHNOLOGY (1967-2017) - 50 LET/50 YEARS}

\section{A. KURC-LISIECKA, A. LISIECKI: LASER WELDING OF THE NEW GRADE OF ADVANCED HIGH-STRENGTH STEEL ...}

level of the BM. The impact toughness of the test joints clearly depends on the welding conditions (heat inputs). Although the impact toughness is lower compared to the $\mathrm{BM}$, the fracture mode is ductile.

\section{Acknowledgements}

The article was financed by the University of Dąbrowa Górnicza in Poland. Special thanks are extended to Rafał Lis, a welding engineer from the WIELTON Company for providing the new steel grade and also to dr. Wojciech Pakieła for the experimental support.

\section{REFERENCES}

${ }^{1}$ J. Górka, Weldability of thermomechanically treated steels having a high yield point, Arch. Metall. Mater., 60 (2015), 469-475, doi:10.1515/amm-2015-0076,

${ }^{2}$ A. Grajcar, M. Różański, S. Stano, A. Kowalski, Microstructure characterization of laser-welded Nb-microalloyed silicon-aluminum TRIP steel, J. Mater. Eng. Perform., 23 (2014), 3400-3406, doi:10.1007/s11665-014-1118-1

${ }^{3}$ J. Górka, Changes in the structure and properties of the steel S700MC by heat treatment, Adv. Mat. Res., 1036 (2014), 111-116, doi:10.4028/www.scientific.net/AMR.1036.11

${ }^{4}$ A. Lisiecki, Welding of thermomechanically rolled fine-grain steel by different types of lasers, Arch. Metall. Mater., 59 (2014), 1625-1631, doi:10.2478/amm-2014-0276

${ }^{5}$ W. A. Swiatnicki, Modern steels: design-technologies-propertiesapplications (Guest Editorial), Mater. Sci. Technol., 31 (2015) 755-757, doi:10.1179/0267083615Z.000000000928

${ }^{6}$ A. Grajcar, M.Różański, M.Kaminska, B.Grzegorczyk, Study on non-metallic inclusions in laser-welded TRIP-adied Nb-microalloyed steel, Arch. Metall. Mater., 59 (2014), 1163-1169, doi:10.2478/ amm-2014-0203

${ }^{7}$ A. Grajcar, M. Różański, S. Stano, A. Kowalski, B. Grzegorczyk, Effect of heat input on microstructure and hardness distribution of laser welded Si-Al TRIP-type steel, Adv. Mater. Sci. Eng., 2014 (2014), doi:10.1155/2014/658947

${ }^{8}$ A. Lisiecki: Diode laser welding of high yield steel, Proc. of SPIE Vol. 8703, Laser Technology 2012: Applications of Lasers, 87030S (January 22, 2013), doi:10.1117/12.2013429

${ }^{9}$ L.A. Dobrzanski, M. Bonek, A. Klimpel, A. Lisiecki, Surface layer's structure of X40CrMoV5-1 steel remelted and/or WC alloyed with HPDL laser, Mater. Sci. Forum, 437-4 (2003), 69-72, doi:10.4028/www.scientific.net/MSF.437-438.69
${ }^{10} \mathrm{M}$. Bonek, The investigation of microstructures and properties of high speed steel HS6-5-2-5 after laser alloying, Arch. Metall. Mater., 59 (2014), 1647-1651, doi:10.2478/amm-2014-0280

${ }^{11}$ G. Moskal, A. Grabowski, A. Lisiecki, Laser remelting of silicide coatings on Mo and TZM alloy, Sol. St. Phenom., 226 (2015), 121-126, doi:10.4028/www.scientific.net/SSP.226.121

${ }^{12}$ D. Janicki, High Power Diode Laser Cladding of Wear Resistant Metal Matrix Composite Coatings, Sol. St. Phenom., 199 (2013) 587-592, doi:10.4028/www.scientific.net/SSP.199.587

${ }^{13}$ A. Lisiecki, Titanium matrix composite Ti/TiN produced by diode laser gas nitriding, Metals, 5 (2015), 54-69, doi:10.3390/ met5010054

${ }^{14}$ A. Lisiecki, Welding of thermomechanically rolled fine-grain steel by different types of lasers, Arch. Metall. Mater., 59 (2014), 1625-1631, doi:10.2478/amm-2014-0276

${ }^{15}$ A. Kurc-Lisiecka, W. Ozgowicz, W. Ratuszek, J. Kowalska, Analysis of deformation texture in AISI 304 steel sheets, Sol. St. Phenom., 203-204 (2013), 105-110, doi:10.4028/www.scientific.net/SSP. 203-204.105

${ }^{16}$ R. Burdzik, Ł.Konieczny, Z. Stanik, P. Folęga, A. Smalcerz, A. Lisiecki, Analysis of impact of chosen parameters on the wear of camshaft, Arch. Metall. Mater., 59 (2014), 957-963, doi:10.2478/ amm-2014-0161

${ }^{17}$ R. Burdzik, T. Węgrzyn, Ł. Konieczny, A. Lisiecki, Research on influence of fatigue metal damage of the inner race of bearing on vibration in different frequencies, Arch. Metall. Mater., 59 (2014), 1275-1281, doi:10.2478/amm-2014-0218

${ }^{18}$ J. Kusiński, S. Kac, A. Kopia, A. Radziszewska, M. Rozmus-Górnikowska, B. Major, L. Major, J. Marczak, A. Lisiecki, Laser modification of the materials surface layer - a review paper, Bull. Pol. Acad. Sci. Tech. Sci., 60 (2012), 711-728, doi:10.2478/ v10175-012-0083-9

${ }^{19}$ T. Węgrzyn, J. Piwnik, D. Hadryś, R. Wieszała, Car body welding with micro-jet cooling, J.Arch. Mater. Sci. Eng., 49 (2011), 90-94

${ }^{20} \mathrm{~J}$. Slania, Influence of phase transformations in the temperature ranges of $1250-1000{ }^{\circ} \mathrm{C}$ and $650-350{ }^{\circ} \mathrm{C}$ on the ferrite content in austenitic welds made with T 2312 LRM3 tubular electrode, Arch. Metall. Mater., 50 (2005), 757-767

${ }^{21}$ B. Slazak, J. Słania, T. Węgrzyn, A.P. Silva, Process stability evaluation of manual metal arc welding using digital signals, Mater. Sci. Forum, 730-732 (2013), 847-852, doi:10.4028/www.scientific.net/MSF.730-732.847

${ }^{22}$ K. Janerka, M. Pawlyta, J. Jezierski, J. Szajnar, D. Bartocha, Carburiser properties transfer into the structure of melted cast iron, J. Mat. Proc. Tech., 214(4) (2014), 794-801, doi:10.1016/j.jmatprotec. 2013.11.027

${ }^{23}$ D. Janicki, Disk laser welding of Armor steel, Arch. Metall. Mater., 59 (2014), 1641-1646, doi:10.2478/amm-2014-0279

${ }^{24}$ J. Bodzenta, A. Kaźmierczak, T. Kruczek, Analysis of thermograms based on FFT algorithm, J. Phys. IV, 129 (2005), 201-206, doi:10.1051/jp4:2005129042 